\title{
The Correlation of Scientific Knowledge-Science Process Skills and Scientific Creativity in Creative Responsibility Based Learning
}

\section{Zainuddin}

M.Pd, Universitas Lambung Mangkurat, Indonesia,_zainuddin_pfis@ulm.ac.id

\section{Suyidno}

Dr., Universitas Lambung Mangkurat, Indonesia, suyidno_pfis@ulm.ac.id

Dewi Dewantara

M.Pd, Universitas Lambung Mangkurat, Indonesia,_dewantara_pfis@ulm.ac.id

\section{Saiyidah Mahtari}

M.Pd, Universitas Lambung Mangkurat, Indonesia, saiyidah_pfis@ulm.ac.id

\section{Mohamad Nur}

Prof., Universitas Negeri Surabaya, Indonesia, psmsunesa@yahoo.co.id

\section{Leny Yuanita}

Prof., Universitas Negeri Surabaya, Indonesia, lenyyuanita@unesa.ac.id

\section{Titin Sunarti}

Dr, Universitas Negeri Surabaya, Indonesia, titinsunarti@unesa.ac.id

The purpose of this study was to find out the correlation between scientific knowledge and science process skills with scientific creativity in Creative Responsibility Based Learning (CRBL). This study involved 83 students of science, physics, chemistry and biology education at Lambung Mangkurat University, Indonesia. The process of data collection used scientific knowledge tests, science process skills tests, and scientific creativity tests. The results of the study show that: (1) scientific knowledge and scientific creativity have a positive, but not significant, relationship. Even though, the mastery of scientific knowledge was needed as a connector of science process skills with scientific creativity; (2) science process skills were positively and significantly correlated with scientific creativity; and (3) both scientific knowledge and science process skills had a simultaneous correlation to scientific creativity.

Keywords: creative responsibility-based learning, science process skills, scientific creativity, scientific knowledge

Citation: Zainuddin, Suyidno, Dewantara, D., Mahtari, S., Nur, M., Yuanita, L., \& Sunarti, T. (2020). The Correlation of Scientific Knowledge-Science Process Skills and Scientific Creativity in Creative Responsibility Based Learning. International Journal of Instruction, 13(3), 307-316. https://doi.org/10.29333/iji.2020.13321a 


\section{INTRODUCTION}

The development of science and technology today has an impact on the problems of human life that are increasingly complex and diverse. Therefore; inevitably, consciously or unconsciously; every individual is required to be more creative in dealing with various issues of life that develop rapidly (Vidergor, Givon, \& Mendel, 2019; Yusnaeni, Corebima, Susilo, \& Zubaidah, 2017). Global Citizenship Education (Unesco, 2014) recommends that higher education should facilitate students to analyze real-life issues critically, to identify possible creative and innovative solutions. Creativity will produce creative generations having potency to solve complex social and environmental issues (Yusnaeni et al., 2017). Gifted and Talented International also suggests that scientific knowledge understanding, science process skills, and scientific creativity as a whole can act as a stimulus forum for sharing creative thinking (Yamin, 2010). In improving students' process skills, teachers can apply learning that is appropriate for their experience and scientific competence (Hardianti \& Kuswanto, 2017). Higher education should emphasize the importance of producing scientific knowledge, science process skills, and scientific creativity to generate scientifically educated individuals (Ghanizadeh \& Jahedizadeh, 2017; Ozdemir \& Dikici, 2017; Setiawan, 2017). Therefore; students are not sufficiently equipped with scientific knowledge, but they must be able to integrate scientific knowledge and science process skills as the main driver of scientific creativity. The integration of scientific knowledge, process skills, and scientific creativity are the main objectives of learning physics in class. It is believed to be able to print the nation's future generations that are creative, innovative, flexible, and adaptive in overcoming the various impacts of the development of science and technology in the future.

Various research findings have pointed out that the development of scientific creativity depends on scientific knowledge and science process skills (Hu \& Adey, 2010; Hu et al., 2013; Siew, Chong, \& Chin, 2014). Science process skills enable the students to understand how science is performed, to carry out scientific investigations, and improve their learning responsibilities (Dementiy \& Grogoleva, 2016; Duda, Susilo, \& Newcombe, 2019). Students who must be able to think rationally, to deal with new situations, and to solve problem situations (Dostál, 2015). Science process skills are components of scientific creativity that contribute significantly to scientific discovery (Farsakoglu, Sahin, \& Karsli, 2012; Hardianti \& Kuswanto, 2017; Hu \& Adey, 2010; Nur, 2014; Siew et al., 2014). Thus, higher education should facilitate the development of scientific knowledge, science process skills, and scientific creativity of the students comprehensively in the learning process in the classroom. Thus, there are no studies that examine the correlation between specific scientific knowledge - science process skills and scientific creativity. Therefore, this study will analyze how the correlation between scientific knowledge - science process skills and scientific creativity.

Various innovative learning models can be applied to beef up scientific knowledge, science process skills, and scientific creativity of the students, one of which is Creative Responsibility Based Learning (CRBL). CRBL is an innovative learning design that facilitates the students' responsibility in enhancing their scientific knowledge, science 
process skills, and scientific creativity (Suyidno, Dewantara, Nur, \& Yuanita, 2017; Suyidno, Nur, \& Yuanita, 2018; Suyidno, Nur, Yuanita, \& Prahani, 2017; Suyidno, Nur, Yuanita, Prahani, \& Jatmiko, 2017). Furthermore, the development of the model following John Dewey's problem-solving path that the classroom should reflect the laboratory of investigations and real-life problem solving (Suyidno et al., 2018); scientific creativity emphasizes more on creative science experiments (Hu \& Adey, 2010), finding and solving creative science problems, and creative science activities: as well as advanced learning theories (constructivism, metacognition, social learning, complex cognitive process, advanced organizer, and scaffolding). The CRBL syntax is presented in Table 1.

Table 1

CRBL Syntax

\begin{tabular}{|c|c|}
\hline Phases & Lecturer's activities \\
\hline $\begin{array}{l}\text { 1. Generating creative } \\
\text { responsibility }\end{array}$ & $\begin{array}{l}\text { Motivate the students by asking them about the function of } \\
\text { objects for scientific purposes, and then convey the objective } \\
\text { of learning and the importance of responsibility for being a } \\
\text { creative person. }\end{array}$ \\
\hline $\begin{array}{l}\text { 2. Organizing the needs of } \\
\text { creative learning }\end{array}$ & $\begin{array}{l}\text { Help the students understand logistics for investigations, and } \\
\text { then direct those to form groups of } 4-6 \text { members and } \\
\text { distribute the logistics needed. }\end{array}$ \\
\hline $\begin{array}{l}\text { 3. Guiding the } \\
\text { investigation in groups }\end{array}$ & $\begin{array}{l}\text { Grow the students' responsibility in experimental activities } \\
\text { and review information sources to solve scientific problems } \\
\text { creatively. }\end{array}$ \\
\hline $\begin{array}{l}\text { 4. Actualization of creative } \\
\text { responsibility }\end{array}$ & $\begin{array}{l}\text { Strengthening the students' responsibility in examining } \\
\text { product examples, making creative products according to the } \\
\text { scientific creativity task, then communicating their work in } \\
\text { class. }\end{array}$ \\
\hline $\begin{array}{l}\text { 5. Evaluating and } \\
\text { reflecting }\end{array}$ & $\begin{array}{l}\text { Involve the students in the evaluation of science process } \\
\text { skills, responsibility, and scientific creativity, along with their } \\
\text { follow-up. }\end{array}$ \\
\hline
\end{tabular}

This study aimed to find out the correlation between scientific knowledge and science process skills with scientific creativity in CRBL.

\section{METHOD}

This study was a correlational study that was intended to find out whether or not there is a correlation between scientific knowledge and science process skills with students' scientific creativity after following CRBL. The subjects of the study were 83 students of science, physics, chemistry and biology education on FKIP at Lambung Mangkurat University, Banjarmasin, Indonesia who were taking the course of basic physics in the academic year 2015/2016.

This study was a correlational study that was intended to find out whether or not there is a correlation between scientific knowledge and science process skills with students' scientific creativity after following CRBL. The subjects of the study were 83 students of 
science, physics, chemistry and biology education on FKIP at Lambung Mangkurat University, Banjarmasin, Indonesia who were taking the course of basic physics in the academic year 2015/2016. In this study, there were three variables, namely two independent variables and one dependent variable. The independent variables in this study were scientific knowledge (X1) and science process skills (X2); while the dependent variable was the students' scientific creativity (Y). The research design can be seen in Figure 1.

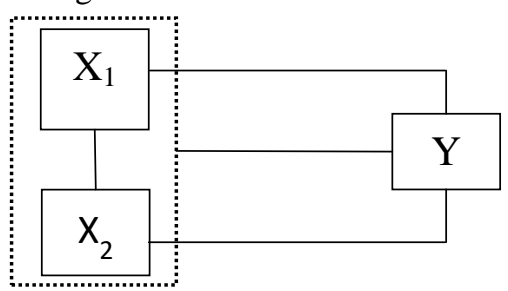

Figure 1

Research Design
Note:

$\mathrm{X} 1$ : The variable of scientific knowledge

$\mathrm{X} 2$ : The variable of science process skills

Y: The variable of scientific creativity

The operational definitions of variables in this study were: (1) scientific knowledge is the whole result of human understanding obtained by using scientific methods. In this study, scientific knowledge was measured using the instrument of the test sheets of scientific knowledge; (2) science process skills emphasized on the indicators of formulating problems, formulating hypotheses, identifying variables, making operational definitions of variables, designing the tables of observational data, designing experimental procedures, analyzing data, and drawing conclusions. The data of science process skills were measured using the instrument of the test sheets of science process skills adapted from science process skills assessment (Nur, 2011); (3) scientific creativity emphasized on the indicators of unusual uses, problem finding, product improvement, scientific imagination, creatively experiment designing, creatively science problem solving, and creatively product design. The data of scientific creativity were measured using the instrument of the test sheets of scientific creativity adapted from Scientific Creativity Assessment (Hu \& Adey, 2010). Before being used, the three instruments had been validated by three experts in physics learning and approved that they had fulfilled the criteria of validity and reliability to be the research instruments (Suyidno et al., 2018; Suyidno, Nur, Yuanita, \& Prahani, 2017).

The hypotheses in this study can be presented below:

(1) There is a positive and significant correlation between scientific knowledge and scientific creativity of students who experience CRBL.

(2) There is a positive and significant correlation between science process skills and the scientific creativity of students who experience CRBL.

(3) There is a simultaneous and significant correlation between scientific knowledge and science process skills of the students who experience CRBL with their scientific creativity. 
The first and second hypotheses testing was undertaken using bivariate correlate analysis. The third hypothesis testing was done using multiple linear regression analysis. Data analyses were done by the aid of SPSS.

\section{FINDINGS}

The technique of data analysis began with prerequisite tests namely normality test, linearity test, and multicollinearity test. The results of the normality test by using the Kolmogorov-Smirnov test revealed that the significance values of the variables of scientific knowledge, science process skills, and scientific creativity respectively were $0.07 ; 0.20 ; 0.06$. The values of these three variables were higher than 0.05 at a $5 \%$ significance level so that the three research variables had a normal distribution. The results of the linearity test by using F-test between scientific knowledge and scientific creativity, and between science process skills and scientific creativity demonstrate that the significance values of $\mathrm{F}$ respectively were 1.39 and 1.51 ; considering that the significance values of $\mathrm{F}$ were higher than 0.05 then there was a linear regression line. Also, the results of the multicollinearity test pointed out that the tolerance value was 0.98 and VIF (Variance Inflation Factor) value was 1.01. The tolerance value was above 0.1 and the VIF value was above 10 , meaning that there was no multicollinearity and the analysis could proceed.

Bivariate analysis was used to test the first and second hypotheses which were to test the coefficient of dependent and independent variables. The results of the bivariate analysis are presented in Table 2 .

Table 2

Results of Bivariate Correlation Testing

\begin{tabular}{llrrr}
\hline & & $\begin{array}{c}\text { Scientific } \\
\text { knowledge }\end{array}$ & $\begin{array}{c}\text { Science } \\
\text { process skills }\end{array}$ & $\begin{array}{c}\text { Scientific } \\
\text { creativity }\end{array}$ \\
\hline Scientific & Pearson Correlation & 1 & .10 & .06 \\
knowledge & Sig. (2-tailed) & & .34 & .54 \\
& $\mathrm{~N}$ & 83 & 83 & 83 \\
Scientific & Pearson Correlation & .10 & 1 & .49 \\
Process Skills / & Sig. (2-tailed) & .34 & & .00 \\
SPS & $\mathrm{N}$ & 83 & 83 & 83 \\
scientific & Pearson Correlation & .06 & .49 & 1 \\
creativity & Sig. (2-tailed) & .54 & .00 & \\
& $\mathrm{~N}$ & 83 & 83 & 83 \\
\hline
\end{tabular}

Note: Correlation is significant at the 0.01 level (2-tailed).

The third hypothesis to be tested was the relationship between the scientific knowledgescience process skills and the scientific creativity of the students following CRBL. The equation of the regression line concerning the relationship between scientific knowledge, the scientific process skill, and scientific creativity is as follows:

$Y=34.94+0.35 X_{1}+10.23 X_{2}$ 


\section{DISCUSSION}

\section{Relationship between Scientific Knowledge and Scientific Creativity}

Table 2 shows that the correlation between scientific knowledge and scientific creativity was very low which was +0.06 with the sig coefficient (2-tailed) of 0.54 . This result was greater than 0.05; therefore, it can be said that after students followed CRBL, there was no significant correlation between scientific knowledge and their scientific creativity. Thus, the increasing scientific knowledge of students affects their scientific creativity but this is not significant. These results are contradictory with the previous studies that scientific knowledge had a significant effect on scientific creativity (Florence, Mark, \& Wachanga, 2015; Karsli \& Şahin, 2009; Usta \& Akkanat, 2015).

Like the Problem Based Learning (PBL); CRBL is not designed to teach the majority of scientific knowledge, but it is designed to maximize the students' responsibility and scientific process skill to develop their scientific creativity. Scientific creativity is a connecting factor between scientific knowledge possessed by its application in solving real-life problems. Scientific knowledge mastery is a prerequisite before a scientific investigation and the tasks of scientific creativity are carried out. Therefore; to overcome differences in student knowledge, in phase 2 of the CRBL, the teacher tries to check the initial provision of students' scientific knowledge and facilitate a variety of relevant information sources. Thus, there is no significant correlation between students' scientific knowledge and scientific creativity in CRBL. It is designed to teach students the responsibilities, science process skills, and scientific creativity; while scientific knowledge is only a nurturing effect of the learning environment with CRBL.

\section{Relationship between Science Process Skills and Scientific Creativity}

Table 2 shows that the correlation between scientific process skills and scientific creativity was was +0.49 with the sig coefficient (2-tailed) of 0.00 . This result was lower than 0.05 . So, Science process skills were positively and significantly correlated to scientific creativity. Improving students' science process skills will simultaneously enhance their scientific creativity. This positive relationship is due to the scientific process skills which are included as the scientific components (Farsakoglu et al., 2012; Hu \& Adey, 2010; Nur, 2014). Furthermore, the correlation equation 1 shows that the implementation of CRBL can improve students' science process skills in formulating problems, formulating hypotheses, identifying variables, making operational definitions of variables, designing observational data tables, designing experimental procedures, conducting experiments, analyzing data, and drawing conclusions. When the skills are well mastered, the students' scientific creativity including unusual uses, problem finding, product improvement, science problem solving, creatively experiment designing, and creatively product design will improve as well. This finding is in line with the results of the previous study which showed the significant contribution of science process skills to the improvement of scientific creativity (Hu et al., 2013; Siew et al., 2014). 


\section{Relationship between Scientific Knowledge-Science Process Skills and Scientific Creativity}

The equation of the regression line concerning the relationship between scientific knowledge, the scientific process skill, and scientific creativity is as follows:

$Y=34.94+0.35 X_{1}+10.23 X_{2}$

The above equation shows the value of the coefficient of scientific knowledge and the scientific process skills of 0.35 and 10.23 respectively. This result indicates that if the value of students' scientific knowledge increases 1 point, then the value of scientific creativity will increase by 0.35 points (assuming the value of the science process skill is fixed).

Table 2 shows a significant relationship between the variables of scientific knowledge, the skills of the scientific process and scientific creativity. Consistent with Table 3; the simultaneous contribution of scientific knowledge and science process skills was $24.1 \%$; while, about $75.9 \%$ was strongly determined by other variables that were not examined in this study. This is probably caused by the development of students' scientific creativity that requires a complex effort, and many factors that influence the mastery level of scientific knowledge and their science process skills (Suyidno et al., 2018). Additionally, the development of scientific creativity is included as a need for learning and innovation skills (Blascova, 2014). This is reinforced by the equation of the regression line indicates that if the value of students' scientific knowledge increases 1 point, then the value of scientific creativity will increase by 0.35 points (assuming the value of the science process skill is fixed). Besides, if the score of students' science process skills increases 1 point, then the value of students' scientific creativity will increase by 10.23 points (assuming students' scientific knowledge is fixed). Scientific knowledge and science process skills simultaneously affect the improvement of scientific creativity. Although Table 2 shows that students' scientific knowledge is not significantly correlated with scientific creativity, the direction of correlation shows a positive direction. Thus, the mastery of scientific knowledge is indispensable as a link between scientific process skills and scientific creativity (Ozdemir \& Dikici, 2017). Scientific process skills have contributed enormously to the development of scientific creativity (Astutik \& Prahani, 2018). This can happen because CRBL is designed to facilitate the student's responsibility to improve scientific knowledge, scientific process skills, and scientific creativity. The CRBL follows the path of John Dewey problem solving in which a real-life investigation and problem-solving laboratory should be reflected in the class, as well as scientific creativity which is more emphasized on creative science experiments, finding and solving science problems creatively, and creative science activities (Suyidno et al., 2018; Suyidno, Nur, Yuanita, Prahani, et al., 2017). This is in line that to create learning settings with more focus on teaching strategies, approaches, and methods that would enable students to participate more actively in the process of learning and teaching from the cognitive, affective, and behavioral aspects (Sezer, Inel, Seckin, \& Ulucinar, 2017). Students build structure their knowledge and link their old knowledge with new and daily knowledge through active 
class participation. Students can be facilitated for success in their work and career in the future (Blascova, 2014; Sitti, Sooperak, \& Sompong, 2013).

\section{CONCLUSION}

The results of CRBL implementation in physics learning show that: (1) scientific knowledge is positively correlated with scientific creativity but not significant; however the direction of the coefficient value shows positive correlation indicating that the mastery of scientific knowledge is indispensable as a medium to link scientific process skills and scientific creativity; (2) science process skills are positively and significantly correlated with scientific creativity. Scientific process skills are the important components of scientific creativity, and (3) scientific knowledge and scientific process skills together correlate with the development of scientific creativity. Thus, implementing CRBL enhances the scientific knowledge and skills of students' science processes which have simultaneous contributions to the development of their scientific creativity. Further studies are necessarily needed to test the effectiveness of CRBL in enhancing scientific knowledge, scientific process skills, and scientific creativity in learning in elementary and secondary education.

\section{REFERENCES}

Astutik, S., \& Prahani, B. K. (2018). The practicality and effectiveness of the collaborative creativity learning (CCL) model by using PhET simulation to increase students' scientific creativity. International Journal of Instruction, 11(4), 409-424.

Blascova, M. (2014). Influencing academic motivation, responsibility, and creativity. Procedia - Social and Behavioral Sciences, 159(2014), 415 - 425.

Dementiy, L. I., \& Grogoleva, O. Y. (2016). (2016). The structure of responsibility for preschool and primary school-age children. Procedia-Social and Behavioral Sciences, 233(2016), 372-376.

Dostál, J. (2015). The definition of the term "Inquiry-based instruction." International Journal of Instruction, 8(2), 69-82.

Duda, H. J., Susilo, H., \& Newcombe, P. (2019). Enhancing different ethnicity science process skills: problem-based learning through practicum and authentic assessment. International Journal of Instruction, 12(1), 1207-1222.

Farsakoglu, O. M., Sahin, C., \& Karsli, F. (2012). Comparing science process skills of prospective science teachers: A cross-sectional study. Asia-Pacific Forum on Science Learning and Teaching, 13(1), 1-22.

Florence, K. W., Mark, O. O., \& Wachanga, M. P. (2015). A correlation study of secondary students' academic achievement in chemistry and their scientific creativity in chemistry. International Journal of Scientific Research and Innovative Technology, 2(5), 1408-1415.

Ghanizadeh, A., \& Jahedizadeh, S. (2017). Validating the Persian version of the reflective thinking questionnaire and probing Iranian University students' reflective 
thinking and academic achievement. International Journal of Instruction, 10(3), 209226.

Hardianti, T., \& Kuswanto, H. (2017). Difference among levels of inquiry: process skills improvement at senior high school in Indonesia. International Journal of Instruction, 10(2), 119-130.

Hu, W., \& Adey, P. (2010). A scientific creativity test for secondary school students. International Journal of Science Education, 24(4), 389-403.

Hu, W., Wu, B., Jia, X., Yi, X., Duan, C., \& Meyer, W. (2013). Increasing student's scientific creativity: The "learn to think" intervention program. The Journal of Creative Behavior, 47(1), 3-21.

Karsli, F., \& Şahin, Ç. (2009). Developing worksheets based on science process skills: Factors affecting solubility. Asia-Pacific Forum on Science Learning and Teaching, $10(1), 1-12$.

Nur, M. (2011). Modul keterampilan-keterampilan proses sains (Science Process Skill Module). Surabaya: Pusat Sains dan Matematika Sekolah, Universitas Negeri Surabaya.

Nur, M. (2014). Berpikir kreatif (Creative thinking). Surabaya: Universitas Negeri Surabaya.

Ozdemir, G., \& Dikici, A. (2017). Relationships between scientific process skills and scientific creativity: Mediating role of nature of scientific knowledge. Journal of Education in Science, Environment and Health, 3(1), 52-68.

Setiawan, R. (2017). The influence of income, experience, and academic qualification on early childhood education teachers' creativity in Semarang, Indonesia. International Journal of Instruction, 10(4), 39-50.

Sezer, A., Inel, Y., Seckin, A. Ç., \& Ulucinar, U. (2017). The relationship between attention levels and class participation of first-year students in classroom teaching departments. International Journal of Instruction, 10(2), 55-68.

Siew, N. M., Chong, C. L., \& Chin, K. O. (2014). Developing a scientific creativity test for fifth graders. Problems of Education in the 21 st Century, 62, 109-123.

Sitti, S., Sooperak, S., \& Sompong, N. (2013). Development of instructional model based on connective learning theory to enhance problem-solving skills in ICT for daily life of higher education students. Procedia - Social and Behavioral Sciences, 103(2013), 315-322.

Suyidno, Dewantara, D., Nur, M., \& Yuanita, L. (2017). Maximize student's scientific process skill within creatively product designing: creative responsibility based learning. In Proceeding The 5th South East Asia Development Research (SEA-DR) International Conference.

Suyidno, Nur, M., \& Yuanita, L. (2018). Model Creative Responsibility Based Learning (CRBL) untuk Meningkatkan Keterampilan Proses Sains, Tanggung Jawab, dan 
Kreativitas Ilmiah Mahasiswa. Disertasi Pascasarjana Unesa. Tidak Dipublikasikan.

Suyidno, Nur, M., Yuanita, L., \& Prahani, B. K. (2017). Validity of creative responsibility based learning: An innovative physics learning to prepare the generation of creative and responsible. Journal of Research \& Method in Education, 7(1), 56-61.

Suyidno, Nur, M., Yuanita, L., Prahani, B. K., \& Jatmiko, B. (2017). Effectiveness of creative responsibility based teaching model on basic physics learning to increase student's scientific creativity and responsibility. Journal Baltic Science of Education, 17(1), 136-151.

Unesco. (2014). Global citizenship education: Preparing learners for the challenges of the 21 st century. The United Nations Educational, Scientific and Cultural Organization.

Usta, E., \& Akkanat, C. (2015). Investigating the scientific creativity level of seventhgrade students. Procedia-Social and Behavioral Sciences, 191(2015), 1408-1415.

Vidergor, H. E., Givon, M., \& Mendel, E. (2019). Promoting future thinking in elementary and middle school applying the Multidimensional Curriculum Model. Thinking Skills and Creativity, 31(2019), 19-30.

Yamin, T. S. (2010). Scientific creativity and knowledge production: Theses, critique, and implications. Gifted and Talented International, 25(1), 7-12.

Yusnaeni, Corebima, A. D., Susilo, H., \& Zubaidah, S. (2017). Creative thinking of low academic students undergoing search solve create and share learning integrated with metacognitive strategy. International Journal of Instruction, 10(2), 245-262. 